\title{
Youth and Emerging Adults: The Changing Contexts of Faith and Giving
}

\author{
Patricia Snell Herzog (iD) \\ Department of Sociology \& Criminal Justice, University of Arkansas, 218 Old Main Building, Fayetteville, \\ AR 72701, USA; herzog@uark.edu
}

Received: 28 June 2017; Accepted: 5 July 2017; Published: 7 July 2017

\section{Introduction}

This is a book about young people-youth and emerging adults. The contributors in this volume investigate the religious and spiritual lives of young people, especially as they relate to inclinations to do good for others. People are increasingly interested in, concerned about, and excited for the generational changes occurring to faith and giving, as young people become adults. Emerging adulthood and the millennial generation receive considerable scholarly and public press attention. Prior generations wonder: What will happen to the future of faith and giving, and how can we help the new generation emerge into adult leaders? Younger generations wonder: How can we reshape the future of faith and giving, and how can existing religious and civic organizations respond to younger generations?

This edited volume is the result of a special issue that invited social scientific insights on responses to these questions. The background for this volume, summarized below, is the evolving life course developmental processes, as well as the culmination of numerous social and cultural changes in recent decades and their implications for socialization of religiosity, spirituality, and generosity. The included chapters focus on the faith and giving of youth and emerging adults, in the United States and internationally. The emphasis is on research that contributes breadth to social scientific understandings of religion, charitable giving, volunteering, generosity, youth, and emerging adults. We are especially interested in trends related to participation in religious and civic organizations, including changing cultural structures, beliefs, and orientations to faith and giving in less formal or non-organizational contexts.

\section{Changing Trends}

Scholars identify certain adulthood transitions as critical moments in the life course. The series of events when emerging adults negotiate their own experiences with those instilled by their upbringing begin to firmly set their adulthood patterns (e.g., (Tanner 2006)). For individuals, this emerging adulthood life stage is characterized by exuberant hope and optimism for personal futures (e.g., (Arnett 2015)). However, a number of troubling social trends have developed in recent decades. Trends for the past 50 years indicate significant growth in relative income for those with the highest incomes, compared to stagnation across time for those with lowest incomes (Russell Sage Foundation 2012). Income earnings significantly associate with educational attainment (NCES 2015) and educational opportunities have become increasingly associated with family income levels, even net of standardized test scores (Putnam 2015). Particularly vulnerable are those who cannot invest in a college degree or the extended duration period often needed for successful adulthood launches (e.g., (Settersten and Ray 2010)).

Partially due to rising college enrollment, within-college differences are increasingly found to be important in predicting life course trajectories (Arum and Roksa 2014; Hamilton 2013; Hällsten 2010; Bozick 2007). At great risk are those ending with only some college, who can incur debt while 
pursuing college courses but without the degree to afford the interest, contributing to multiple financial strains and even bankruptcy (e.g., (Porter 2012, chp. 1, pp. 1-24, chp. 5, 85-100)). Moreover, emerging adults have varied cultural capital upon which to rely as they navigate their adult pathways. This leads to calling upon mixed, and sometimes overtly contradictory, advice as they attempt to make use of the large, bureaucratic, and impersonal settings of higher education and workplaces, and more generally rests futures too heavily on extant parent knowledge regarding complex issues (e.g., (Lareau 2011; 2015)).

Perceptions that adulthood transitions are merely a matter of individual choices and preferences, coupled with the hyper-self-focus of the life stage, can obscure the real social inequalities in adulthood pathways (e.g., (Osgood et al. 2005; Porter 2012; Radmacher and Azmitia 2013; Silva 2013)). Such misperception is enabled by rapid fluctuations in adulthood statuses during emerging adulthood complicating traditional social status measures. For example, month-to-month employment studies reveal that only 13 percent of university graduates had the same employer even one year later, and that 37 percent had a different employer at each of one, three, and five years after graduation (Krahn et al. 2014). Being among the rare minority with employment stability matters for future outcomes. One result of the extended transition to adulthood is the duration spent in low-wage labor positions (Carnevale et al. 2013). Even more troubling is the rising proportion of youth who are entirely disconnected from primary social institutions, namely school and work. This number rose by one-third in the previous ten years to nearly 15 percent in 2010 and is predictive of a range of problematic outcomes (Wight et al. 2010). Such vulnerabilities present challenges to sustaining participation in faith and giving.

Combined, these trends indicate the need for extra-familial organizations to contribute to the formation of emerging leaders in ways that span inequality and generational disconnects. However, Arum and Roksa (2010) find that 45 percent of college students in 24 higher education institutions demonstrate no significant improvement in their critical thinking, complex reasoning, or writing skills during first years of college. On average, it seems that the trends above, coupled with competing pressures of higher education, leave college graduates less prepared to launch successfully into leadership positions, or even to contribute successfully to organizations or be employed be them. In interviews with 30 different employers spanning 11 employment sectors, Konstam (2015) finds that managers experience a marked disconnect with their Millennial employees exemplified by this employer quote: "There is a tension between the values that many Millennials were taught when they were growing up and the harsh reality of what the 'real world' expects from them" (p. 163). Employers agree that Millennials lack needed skills and experience disillusionment with organizational realities.

Moreover, the extensive organizational participation of past generations supported previous transitions to adulthood roles by having non-familial adults to whom youth could turn for advice, support, and role modeling (Putnam 2000, 2015). As the pathway to adulthood has become less structured, regular civic and religious organizational participation has markedly declined. This decline in civic and religious participation has decreased the range of opportunities for youth to gain access to essential civic skills and moral values (Smith and Herzog 2009; Snell 2010).

For more information on these trends, see also Herzog and Price 2016; Glass et al. 2015; Lareau 2015; Sumner et al. 2015; Cherlin 2014; Cooper 2014; Dunkelman 2014; Pinker 2014; Sawhill 2014; Branje et al. 2014; Carbone and Cahn 2014; Barban and Billari 2012; Shulman and Connolly 2013; Buchmann 2012; Liefbroer and Elzinga 2012; Russell Sage Foundation 2012; Goldscheider 2012; Reynolds and Johnson 2011; Smith et al. 2011; Carlson and England 2011; Salmela-Aro et al. 2011; Massoglia and Uggen 2010; Mullen 2010; Peterson and Krivo 2010; Lareau and Conley 2010; Robette 2010; Macomber et al. 2009; Mayer 2009; Widmer and Ritschard 2009; Fuller 2008; Smith et al. 2008; Aassve et al. 2007; Billari et al. 2006; Hillmert 2005; Billari and Piccarreta 2005; Billari 2001; Arnett 2000; Gamoran 1992; Moen et al. 1992; Gove et al. 1989; Mare et al. 1984; Snell 2009. 


\section{Need for New Studies}

Given these trends, more studies are needed that investigate social institutional leadership in guiding millennial youth in their transition to adulthood. For example, merging insights from the National Study of Youth \& Religion (National Study of Youth \& Religion 2013) and the Science of Generosity (e.g., (Herzog and Price 2016)) Figure 1 presents data on the religious and giving patterns of NSYR participants during their early emerging adulthood in Wave 4, collected in 2013. Figure 1 shows religious participation stability and change between Waves 3 , when many participants were still living in their parents' homes, to Wave 4, when most were at least semi-independent from their parents' residences. There are three stable trends, of which stability in never attending (far left) is the highest, then stable sometimes attending (middle), and stable in regularly attending (far right). There is net decline in religious attendance during these waves, with the decline to never (left-middle) category being larger than the incline to regularly attending (right-middle). Thus, the trend is to further increases in religious "nones," or those who never attend religious services, which were already the largest group heading into emerging adulthood.

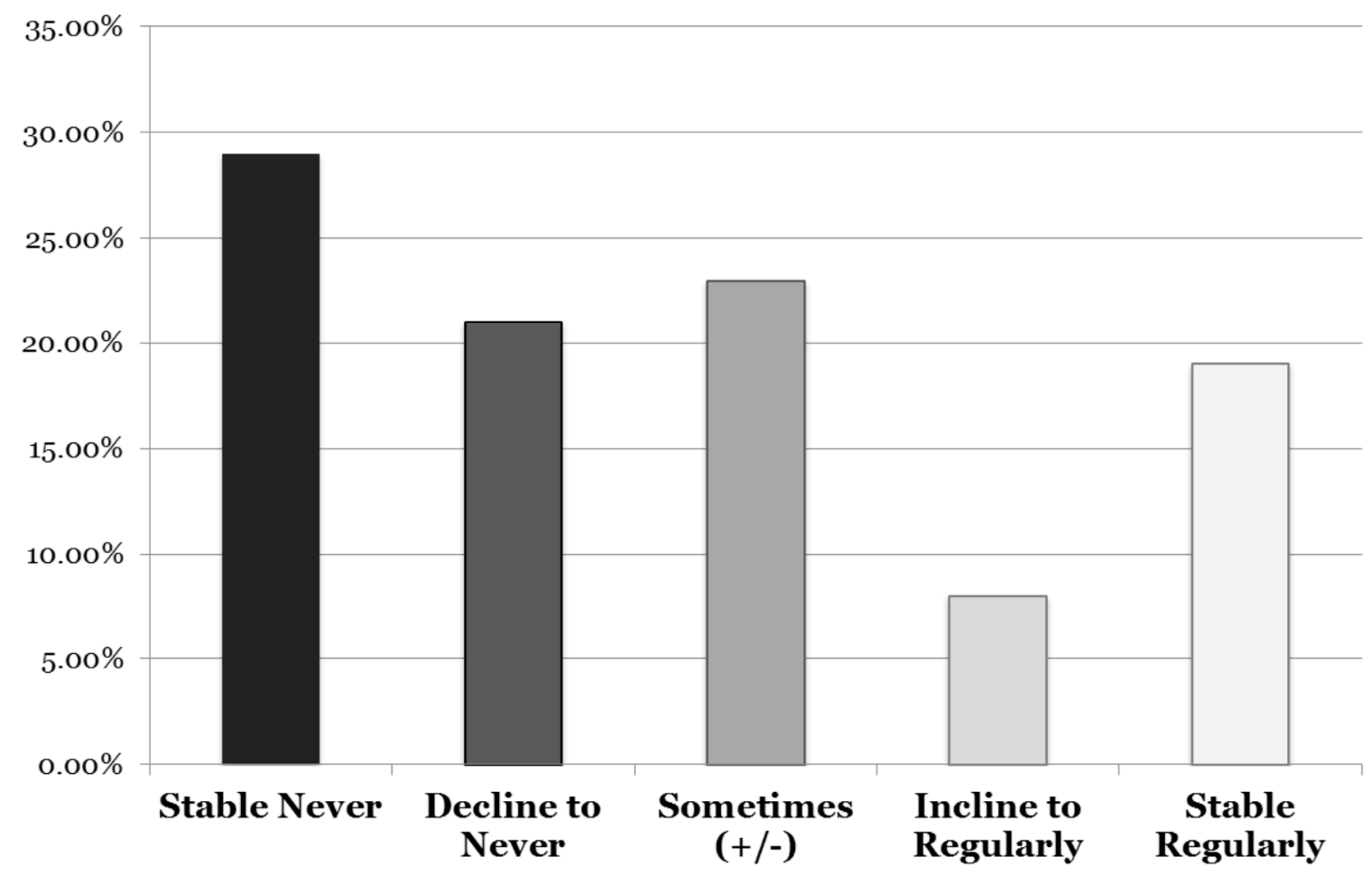

Source: National Study of Youth \& Religion (NSYR) - Religious Participation Changes from Wave 3 ( 18 to 23 years old in 2008) to Wave 4 Changes ( 23 to 27 years old in 2013)

Figure 1. Religious Participation Over Time in Adulthood Transitions.

However, in assessing stability and change patterns in charitable giving during early emerging adulthood, the reverse trend is found. Figure 2 shows that 31 percent are a stable no for charitable giving between Waves 3 and 4, while 25 percent are a stable yes. However, only 10 percent decline from giving at Wave 3 to not giving at Wave 4. Conversely, 34 percent of emerging adults who were non-givers at Wave 3 became givers by Wave 4. Combining stability and change in religiosity and charitable giving, preliminary analyses show religious participation patterns related to giving stability. However, further investigation reveals a more complex, non-linear picture. Religious "nones" and sometimes attenders are about equal in those who decline from being a giver to not and in those who incline to becoming a giver across waves. Yet, inclines to becoming givers have a greater proportion of those who stably regularly attend or incline to becoming a regular attender across waves. Together, 
these results raise many questions, which we cannot yet well answer with existing data because previous studies reveal the need to inquire further about these issues.

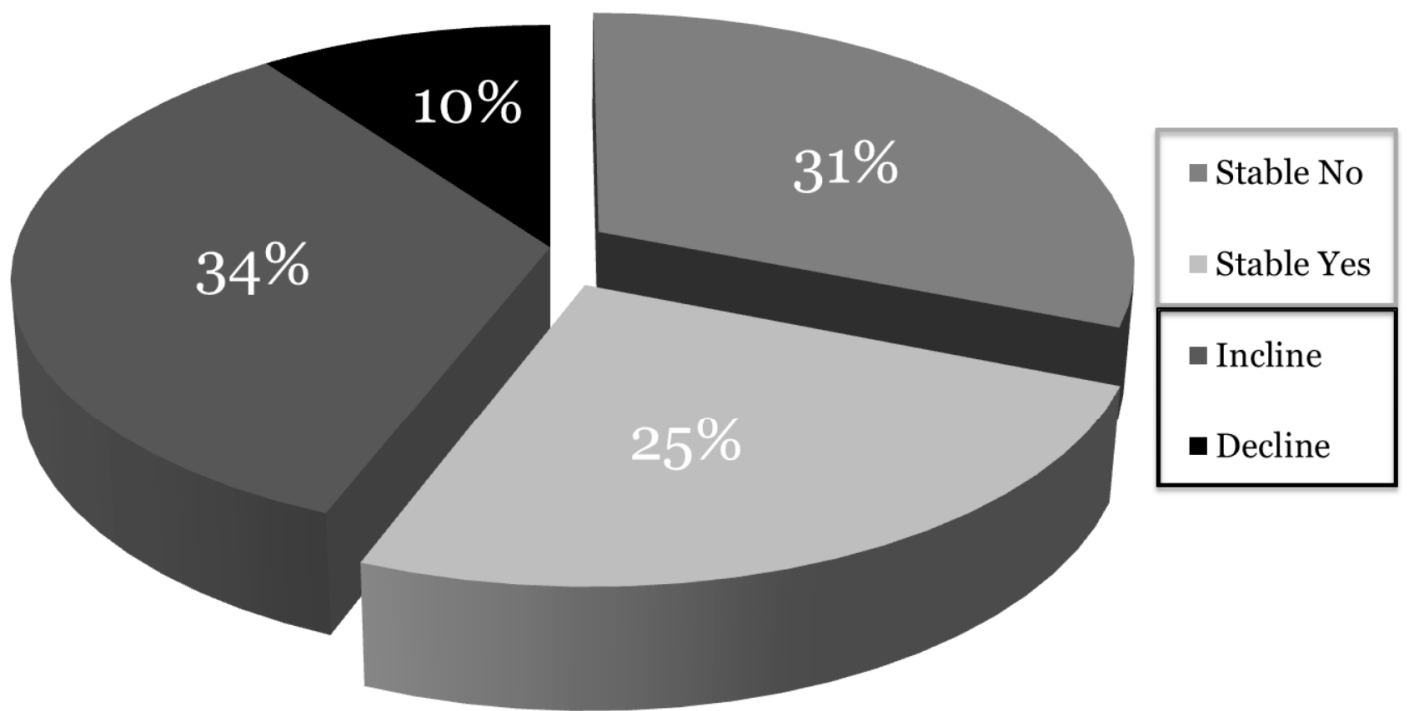

Source: National Study of Youth \& Religion (NSYR) - Comparison of Status of Financial Giving to Charitable Causes from Wave 3 (18 to 23 years old in 2008) to Wave 4 Changes (23 to 27 years old in 2013)

Figure 2. Changes Over Time in Emerging Adult Financial Giving to Charitable Causes.

Examples of important questions raised by existing studies include: What propels emerging adults to start attending religious services or being charitably giving? What personal and social characteristics support emerging adults in maintaining their current religious and giving commitments through the fluctuations of early adulthood? What is lacking when emerging adults stop previous habits to attend religious services or charitably give once they begin adulthood and feasibly are more able to do both? How can people of faith and civic leaders help with successful adulthood launches? How are Millennials transforming faith and giving; are they involved in ways that are less formally organized and may be missed by typical measures?

My own research identifies work and school as two primary social settings that shape faith and giving, especially as emerging adults have multiple moves and become disconnected from other community organizations in the process. Thus, in asking and answering questions about faith and giving, it is necessary to also investigate emerging adult patterns with school and work. However, traditional academic investigation practices study each of these social institutions in disparate subfields and even different disciplines, causing a disconnect in knowledge gained from viewing emerging adults holistically, as full persons who experience life across an array of social settings simultaneously. Moreover, few studies have adapted data collection to accommodate the $21^{\text {st }}$ century structure of these institutions. New studies are needed that build upon and connect prior knowledge on school, work, faith, and giving in investigating the changing reality of youth religiosity and spirituality.

\section{Disjointed Contexts}

Social and cultural trends have resulted in mostly de-institutionalized pathways to adulthood. Religious and civic organizations formerly provided locally based sites for cross class connections of youth to extra-familial supportive adults, but this is less the case today. Bifurcating inequalities coupled with declining organizational participation. Emerging adults transitioning to adulthood in more disorganized ways have divergent outcomes. Some have the cultural and social capital to navigate the complexities well. Others flounder and sometimes suffer in trying to establish stable adult lives. Formerly distinct organizations, such as churches, nonprofits, business, and universities 
increasingly share in common that the emerging leaders of the Millennial generation tend to distrust social institutions and operate more informally through networked communications. Religious and civic leaders, employers, and educators can feel disconnected from Millennials.

Yet Millennials are hyper-connected to each other, networked horizontally not laterally. Limited cross-generational contact causes disjoints in social institutional leadership preparation. Established leaders ask themselves: "Where are all the young people?" Emerging leaders do not ask themselves (enough): "Where is all the wisdom?" Established leaders of existing social institutions, such as pastors, often find themselves at a loss for how to impact the monumental social and cultural changes surrounding their organizations. Religious and civic organizations are sites for young people to have mentoring by extra-familial adults and to practice valuable organizational skills, such as generosity and commitment. But declining organizational participation by younger generations reduces access to these supports.

Formerly distinct organizations, such as churches, nonprofits, business, and universities now have in common changes ushered in by the Millennial generation, including changing values, different interaction styles, lower levels of organizational trust, and diverse desires from their participation. Religious leaders and Millennials can be disconnected from one another. Meanwhile, Millennials are hyper-connected with each other but often lack intergenerational mentoring and spiritual guidance. Limited cross-generational contact causes disconnects in religious leadership preparations. Established leaders often ask: "How can we engage more young people?" Often millennial emerging leaders ask: "What should I do next, and who can I turn to for guidance?" The disjuncture in these questions indicates that intergenerational connections and understanding can be mutually benefiting.

\section{Book Aims and Commitments}

A central aim of this book is to investigate with a deep commitment to and methodological support for inclusivity. This is a result of knowing that understandings of social life can be dramatically affected by paying attention only to our immediate contexts and reference groups, and of how skewed research results are if studying only those people who are most available for contact. Thus, the works included in this volume are intentionally varied in their geographical contexts, religious traditions, units of analysis, data collection techniques, and focus on religiosity, spirituality, charitable giving, or volunteerism.

A second aim of this book is to be receptive to practice-based knowledge and to conduct social science research in direct communication with young people, or those who have regular contact with young people. This is a result of a philosophy of science approach that is heavily influenced by community-based research, (Barnes et al. 2016) which is skeptical of knowledge constructed in academic "vacuums," and instead prioritizes a reverse of the traditional academic-practitioner hierarchy by recognizing community leaders as the experts and sees researchers as facilitators. Thus, many of the works in this volume give credence to the perspectives of laypeople, those who are not necessarily formally trained in religious theology, in order to learn from the perspectives of ordinary people and practitioners.

Third, this book aims to be innovative in its approach to studying the faith and giving of young people, in order to explore the possibility that social science is itself in need of reorganization. With humility and awareness that prior findings in social science may need updating, the call of this book is influenced by liberation theology approaches to pedagogy (Freire 2000). Thus, the contributors are receptive to learning from research participants their understanding of their activities. Rather than operating with approaches to studying social life that presume the most scientific knowledge is that which operates with a priori expectations that are tested to determine whether evidence positively supports hypotheses, the contributors to this volume were instead prepared to listen well to young people, interpret their data with theoretically informed approaches, and ready to learn from the empirical reality these studies present. 


\section{Chapter Summaries}

The topics of the chapters include: religious nones, volunteerism, public religiosity, ecclesial worker marginalization, multi-faith workplaces, attitudes toward evangelization, charitable sporting events, religious giving, and youth socialization. The research locations, foci, and religious traditions are intentionally varied, resulting in data on Chinese and Japanese youth in the U.S.; black and white youth participation in the Chicago area; adolescent generosity in California; religious transmission of giving practices for youth in northern Indiana; religious youth leaders in the Detroit area; emerging adults in a college course preparing for religiously and culturally diverse workplaces in Northwestern Arkansas; emerging adults exploring religious identification in China; and the volunteerism of emerging adults in South Texas.

Interdisciplinary perspectives were welcomed. In addition to the core social science disciplines of sociology, psychology, political science, anthropology, and economics, insights were sought from human development, education, social work, history, human geography, management and business studies, law, international relations, philosophy, theology, and other relevant fields with applications to these social science questions. Empirical articles are the focus of the volume, and consideration was also given to important theoretical, historical, and philosophical submissions that contribute implications to social scientific inquiry on these topics.

In Chapter 1, sociologists Rhys H. Williams, Courtney Ann Irby, and R. Stephen Warner investigate the religious lives of young adults. They focus on youth organizational participation, and the ways this organizational involvement shapes religious identities and ideas about religious commitment. The black and white youth in the study are in the Chicago area, college-age, and Christians. Black youth tended to employ language of family, home, calling, and community, which highlighted the high degree of integration they had with the larger religious community. In distinction, the white youth in the study instead tended to chronicle their organizational biographies of involvement or disengagement, which highlighted their separation from the larger church community.

The study of Chapter 2 is based in China and also investigates attitudes about Christianity in college students. However, ethnologist Chao Wang finds that in the Chinese context, atheism is the mainstream belief system, and the youth describe their explorations with Christianity as a non-mainstream, non-family-engrained belief system. Though there has been a recent increase in the rate of exposure to Christian beliefs, the youth of this study do not evidence a complementary spike in religious affiliation. This highlights an inquisitive approach to religiosity that, as of yet, has not converted to deeper levels of belonging to a religious tradition.

In Chapter 3, scholars of education, Asian American studies, religious studies, and law, Russell Jeung, Brett Esaki, and Alice Liu investigate Chinese and Japanese American young adults by employing data from the Pew Research Center's 2012 Asian American Survey. Shifting away from a focus on belonging to religious denominations, this study investigates religious rituals and righteousness in ethical relations as "Asian-centric" forms of spiritual practices and orientations. This study complicates reports of rising religious nones by showing that these young adults, who are technically religious nones, engage in spiritual practices based on ancestor veneration and familial obligations, while also participating in religious festivals. Taken together, these first three chapters highlight (only some of) the complexities of religiosity and spirituality across diverse subcultures of youth and emerging adults.

The fourth chapter bridges to investigating institutional socialization of youth into religiosity and spirituality. the theologians and youth ministers, Michael McCallion, John Ligas, and George Seroka, study youth ministry practices within the Archdiocese of Detroit and find that this formal organization has a weak infrastructure for connecting with youth and young adults. Despite explicit claims to the opposite, the youth ministers report that they are not well-supported and feel marginalized in their ability to remain securely employed in the service of youth. Akin with broader organizational studies, this religious organization has a disconnect between its stated policy and actual practices, which serves 
to undermine concerted efforts to socialize youth and young adults into committed faith and frequent religious practices.

In Chapter 5, the focus on institutional socialization practices continues. Sociology and business lend insights to the research of Patricia Snell Herzog, DeAndre' T. Beadle, Daniel E. Harris, Tiffany E. Hood, and Sanjana Venugopal. They investigate college enrolled emerging adults who participated in a course aimed at preparing them to participate in multi-fait workplaces. Contrary to general cultural trends that find exposure to diverse religious orientations tends to undermine serious religious commitment, this study provides evidence that concerted effort, empathic connection with adherents of diverse faith traditions (including non-faith), mentoring that challenges cliché approaches to moral values, and personal reflection move emerging adults toward deeper levels of critical thinking that supports increases in cultural awareness without the byproduct of moral relativism.

Also employing a life course developmental approach, Chapter 6 investigates how less formalized social settings can contribute to religious and charitable outcomes. Psychologists Nathaniel A. Fernandez, Sarah A. Schnitker, and Benjamin J. Houltberg theorize a model for how participating in a charity marathon training may develop generosity among adolescents. Their model accounts for the complexity of motives by considering meaning-driven spiritual and moral motives, self-driven fitness motives, and relation-driven social motives. They theorize the mechanisms of change as: sanctification of activities, transcendent identity, positive emotions, cognitive dissonance, and group entitativity, which refers to the belongingness and cohesiveness of the group. An empirical model for investigating these effects on generosity is proposed.

In Chapter 7, consideration of the life course developmental effects of religious and spiritual socialization continues in a study of college-enrolled emerging adults in South Texas. Sociologists Reed T. DeAngelis, Gabriel A. Acevedo, and Xiaohe Xu investigate religious transmission across the life course as it relates to secular volunteerism while in college. While childhood religiosity relates to greater rates of volunteerism as an emerging adult, this relationship is mediated by whether emerging adults are religiously active. The implication is that childhood religious socialization, in the absence of continued religious participation, may be "necessary but not sufficient" in supporting giving time as an emerging adult.

The final empirical chapter, Chapter 8, continues an investigation of life course trends in religiosity and generosity. Sociologists Patricia Snell Herzog and Scott Mitchell investigate the intergenerational transmission of religious giving by studying how religiously involved parents, across different religious traditions, teach, model, or otherwise impart giving to their children. This study reveals that giving may have a "delayed onset," meaning it is patterned during childhood but may not be activated until later in the life course once adulthood is established.

The conclusion provides summaries of implications across these eight studies and interprets their relevance for practitioners who work with youth and emerging adults. The audiences for these implications are: college educators, religious and spiritual leaders, and parents. The conclusion also offers a section of remaining questions for studies investigating youth and emerging adults, within their changing religious, cultural, and social contexts.

Keywords: youth; emerging adults; faith; generosity; giving; volunteering; organizational participation

About the Journal: Religions is an international, open access, scholarly journal, publishing peer reviewed studies of religious thought and practice. It is available online to promote critical, hermeneutical, historical, and constructive conversations. Religions promotes interdisciplinary approaches to any of the world's religious and spiritual traditions. It publishes regular research papers, reviews, communications and reports on research projects. Religions aims to serve the interests of a wide range of thoughtful readers and academic scholars of religion, as well as theologians, philosophers, social scientists, anthropologists, psychologists, neuroscientists and others interested in multidisciplinary study of religions.

Acknowledgments: The author thanks Shauna Morimoto, Heather E. Price, Jared Peifer and Casey Harris for their input and discussions surrounding the ideas in this volume. Also instrumental was David King of the Lake Institute in the Lilly Family School of Philanthropy at Indiana University Purdue University Indianapolis, who 
generously funded a Lake Institute Emerging Scholar award that provided the time to craft the introduction to this volume. Special thanks as well to each of the contributors to the volume for their insights about youth and emerging adults.

Conflicts of Interest: The author declares no conflict of interest.

\section{References}

Aassve, Arnstein, Francesco C. Billari, and Raffaella Piccarreta. 2007. Strings of Adulthood: A Sequence Analysis of Young British Women's Work-Family Trajectories. European Journal of Population / Revue Européenne de Démographie 23: 369-88. [CrossRef]

Arnett, Jeffrey J. 2000. High Hopes in a Grim World: Emerging Adults' Views of their Futures. Youth E Society 31: 267-86.

Arnett, Jeffrey J. 2015. Emerging Adulthood: The Winding Rose from the Late Teens through the Twenties, 2nd ed. New York: Oxford University Press.

Arum, Richard, and Josipa Roksa. 2010. Academically Adrift: Limited Learning on College Campuses. Chicago: University of Chicago Press.

Arum, Richard, and Josipa Roksa. 2014. Aspiring Adults Adrift: Tentative Transitions of College Graduates. Chicago: University Of Chicago Press.

Barban, Nicola, and Francesco C. Billari. 2012. Classifying Life Course Trajectories: A Comparison of Latent Class and Sequence Analysis. Journal of the Royal Statistical Society: Series C (Applied Statistics) 61: 765-84. [CrossRef]

Barnes, Sandra L., Lauren Brinkley-Rubinstein, Bernadette Doykos, Nina C. Martin, and Allison McGuire, eds. 2016. Academics in Action: A Model for Community-Engaged Research, Teaching, and Service. New York: Fordham University Press.

Billari, Francesco C. 2001. The Analysis of Early Life Courses: Complex Descriptions of the Transition to Adulthood. Journal of Population Research 18: 119-42. [CrossRef]

Billari, Francesco C., and Raffaella Piccarreta. 2005. Analyzing Demographic Life Courses through Sequence Analysis. Mathematical Population Studies 12: 81-106. [CrossRef]

Billari, Francesco C., Johannes Fürnkranz, and Alexia Prskawetz. 2006. Timing, Sequencing, and Quantum of Life Course Events: A Machine Learning Approach. European Journal of Population / Revue Européenne de Démographie 22: 37-65. [CrossRef]

Bozick, Robert. 2007. Making It through the First Year of College: The Role of Students' Economic Resources, Employment, and Living Arrangements. Sociology of Education 80: 261-85. [CrossRef]

Branje, Susan, Lydia Laninga-Wijnen, Rongqin Yu, and Wim Meeus. 2014. Associations among School and Friendship Identity in Adolescence and Romantic Relationships and Work in Emerging Adulthood. Emerging Adulthood 2: 6-16. [CrossRef]

Buchmann, Marlis C. 2012. Review: Coming of Age in America: The Transition to Adulthood in the Twenty-First Century. Edited by Mary C. Waters, Patrick J. Carr, Maria J. Kefalas and Jennifer Holdaway. American Journal of Sociology 118: 517-19. [CrossRef]

Carbone, June, and Naomi Cahn. 2014. Marriage Markets: How Inequality Is Remaking the American Family. Oxford: Oxford University Press.

Carlson, Marcia, and Paula England, eds. 2011. Social Class and Changing Families in an Unequal America. Stanford: Stanford University Press.

Carnevale, Anthony P., Andrew R. Hanson, and Artem Gulish. 2013. Failure to Launch: Structural Shift and the New Lost Generation. Washington: Center on Education and the Workforce, Georgetown University, Available online: https:/ /cew.georgetown.edu/cew-reports/failure-to-launch/ (accessed on 1 May 2017).

Cherlin, Andrew J. 2014. Labor's Love Lost: The Rise and Fall of the Working-Class Family in America. New York: Russell Sage Foundation Publications.

Cooper, Marianne. 2014. Cut Adrift: Families in Insecure Times. Berkeley: University of California Press.

Dunkelman, Marc J. 2014. The Vanishing Neighbor: The Transformation of American Community, 1st ed. New York: W. W. Norton \& Company.

Freire, Paolo. 2000. Pedagogy of the Oppressed, 30th ed. London: Bloomsbury Academic. 
Fuller, Sylvia. 2008. Job Mobility and Wage Trajectories for Men and Women in the United States. American Sociological Review 73: 158-83. [CrossRef]

Gamoran, Adam. 1992. Review: Getting Started: Transition to Adulthood in Great Britain. By Alan C. Kerckhoff. American Journal of Sociology 97: 1206-8. [CrossRef]

Glass, Jennifer L., April Sutton, and Scott T. Fitzgerald. 2015. Leaving the Faith How Religious Switching Changes Pathways to Adulthood among Conservative Protestant Youth. Social Currents 2: 126-43. [CrossRef] [PubMed]

Goldscheider, Frances K. 2012. The Accordion Family: Boomerang Kids, Anxious Parents, and the Private Toll of Global Competition by Katherine Newman. American Journal of Sociology 118: 821-22. [CrossRef]

Gove, Walter R., Suzanne T. Ortega, and Carolyn Briggs Style. 1989. The Maturational and Role Perspectives on Aging and Self through the Adult Years: An Empirical Evaluation. American Journal of Sociology 94: 1117-45. [CrossRef]

Hällsten, Martin. 2010. The Structure of Educational Decision Making and Consequences for Inequality: A Swedish Test Case. American Journal of Sociology 116: 806-54. [CrossRef]

Hamilton, Laura T. 2013. More Is More or More Is Less? Parental Financial Investments during College. American Sociological Review 78: 70-95. [CrossRef]

Herzog, Patricia Snell, and Heather E. Price. 2016. American Generosity: Who Gives E Why. New York: Oxford University Press.

Hillmert, Steffen. 2005. From Old to New Structures: A Long-Term Comparison of the Transition to Adulthood in West and East Germany. Advances in Life Course Research 9: 151-73. [CrossRef]

Konstam, Varda. 2015. Voices of Employers: Overlapping and Disparate Views. In Emerging and Young Adulthood, Advancing Responsible Adolescent Development. New York: Springer International Publishing, pp. 161-82.

Krahn, Harvey J., Andrea L. Howard, and Nancy L. Galambos. 2014. Exploring or Floundering? The Meaning of Employment and Educational Fluctuations in Emerging Adulthood. Youth \& Society 47: 245-66.

Lareau, Annette. 2011. Unequal Childhoods: Class, Race, and Family Life, 2nd ed. Berkeley: University of California Press.

Lareau, Annette. 2015. Cultural Knowledge and Social Inequality. American Sociological Review 80: 1-27. [CrossRef]

Lareau, Annette, and Dalton Conley, eds. 2010. Social Class: How Does It Work? New York: Russell Sage Foundation Publications.

Liefbroer, Aart C., and Cees H. Elzinga. 2012. Intergenerational Transmission of Behavioural Patterns: How Similar Are Parents' and Children's Demographic Trajectories? Advances in Life Course Research 17: 1-10. [CrossRef]

Macomber, Jennifer Ehrle, Mike Pergamit, Tracy Vericker, Daniel Kuehn, Marla McDaniel, Erica H. Zielewski, Adam Kent, and Heidi Johnson. 2009. Vulnerable Youth and the Transition to Adulthood. Washington: The Urban Institute.

Mare, Robert D., Christopher Winship, and Warren N. Kubitschek. 1984. The Transition from Youth to Adult: Understanding the Age Pattern of Employment. American Journal of Sociology 90: 326-58. [CrossRef]

Massoglia, Michael, and Christopher Uggen. 2010. Settling down and Aging out: Toward an Interactionist Theory of Desistance and the Transition to Adulthood. American Journal of Sociology 116: 543-82. [CrossRef] [PubMed]

Mayer, Karl Ulrich. 2009. New Directions in Life Course Research. Annual Review of Sociology 35: 413-33. [CrossRef]

Moen, Phyllis, Donna Dempster-McClain, and Robin M. Williams Jr. 1992. Successful Aging: A Life-Course Perspective on Women's Multiple Roles and Health. American Journal of Sociology 97: 1612-38. [CrossRef]

Mullen, Ann L. 2010. Degrees of Inequality. Baltimore: Johns Hopkins University Press.

National Study of Youth \& Religion. 2013. Available online: http:/ / youthandreligion.nd.edu/ (accessed on 1 May 2017).

NCES. 2015. The Condition of Education 2015: Annual Earnings of Young Adults. U.S. Department of Education, National Center for Education Statistics. Available online: https://nces.ed.gov/fastfacts/ (accessed on 1 May 2017).

Osgood, D. Wayne, E. Michael Foster, Constance Flanagan, and Gretchen R. Ruth, eds. 2005. On Your Own Without a Net: The Transition to Adulthood for Vulnerable Populations. Chicago: University of Chicago Press.

Peterson, Ruth D., and Lauren J. Krivo. 2010. Divergent Social Worlds: Neighborhood Crime and the Racial-Spatial Divide. Baltimore: Russell Sage Foundation. 
Pinker, Susan. 2014. The Village Effect: How Face-to-Face Contact Can Make Us Healthier, Happier, and Smarter. New York: Spiegel \& Grau.

Porter, Katherine, ed. 2012. Broke: How Debt Bankrupts the Middle Class. Palo Alto: Stanford University Press.

Putnam, Robert D. 2000. Bowling Alone: The Collapse and Revival of American Community. New York: Simon \& Schuster. Putnam, Robert D. 2015. Our Kids: The American Dream in Crisis. New York: Simon \& Schuster.

Radmacher, Kimberley, and Margarita Azmitia. 2013. Unmasking Class How Upwardly Mobile Poor and Working-Class Emerging Adults Negotiate an 'Invisible' Identity. Emerging Adulthood 1: 314-29. [CrossRef]

Reynolds, John R., and Monica Kirkpatrick Johnson. 2011. Change in the Stratification of Educational Expectations and Their Realization. Social Forces 90: 85-109. [CrossRef]

Robette, Nicolas. 2010. The Diversity of Pathways to Adulthood in France: Evidence from a Holistic Approach. Advances in Life Course Research 15: 89-96. [CrossRef]

Russell Sage Foundation. 2012. Chartbook of Social Inequality. Available online: http://www.russellsage.org (accessed on 1 May 2017).

Salmela-Aro, Katariina, Noona Kiuru, Jari-Erik Nurmi, and Mervi Eerola. 2011. Mapping Pathways to Adulthood among Finnish University Students: Sequences, Patterns, Variations in Family and Work-Related Roles. Advances in Life Course Research 16: 25-41. [CrossRef]

Sawhill, Isabel V. 2014. Generation Unbound: Drifting into Sex and Parenthood without Marriage. Washington: Brookings Institution Press.

Settersten, Richard, and Barbara E. Ray. 2010. Not Quite Adults: Why 20-Somethings Are Choosing a Slower Path to Adulthood, and Why It's Good for Everyone. New York: Bantam.

Shulman, Shmuel, and Jennifer Connolly. 2013. The Challenge of Romantic Relationships in Emerging Adulthood Reconceptualization of the Field. Emerging Adulthood 1: 27-39. [CrossRef]

Silva, Jennifer M. 2013. Coming Up Short: Working-Class Adulthood in an Age of Uncertainty. New York: Oxford University Press.

Smith, Christian, and Patricia Snell Herzog. 2009. Souls in Transition: The Religious and Spiritual Lives of Emerging Adults. New York: Oxford University Press.

Smith, Christian, Michael Emerson, and Patricia Snell. 2008. Passing the Plate: Why American Christians Don't Give Away More Money. New York: Oxford University Press.

Smith, Christian, Kari Christoffersen, Hilary Davidson, and Patricia Snell Herzog. 2011. Lost in Transition: The Dark Side of Emerging Adulthood. New York: Oxford University Press.

Snell, Patricia. 2009. What Difference Does Youth Group Make? A Longitudinal Analysis of Religious Youth Group Participation and Religious and Life Outcomes. Journal for the Scientific Study of Religion 48: 572-87. [CrossRef]

Snell, Patricia. 2010. Emerging Adult Civic Disengagement: A Longitudinal Analysis of Moral Values in Explaining Interest in Political Involvement. Journal of Adolescent Research 25: 258-87. [CrossRef] [PubMed]

Sumner, Rachel, Anthony L. Burrow, and Patrick L. Hill. 2015. Identity and Purpose as Predictors of Subjective Well-Being in Emerging Adulthood. Emerging Adulthood 3: 46-54. [CrossRef]

Tanner, Jennifer L. 2006. Recentering During Emerging Adulthood: A Critical Turning Point in Life Span Human Development. In Emerging Adults in America: Coming of Age in the 21st Century. Edited by Jeffrey J. Arnett and Jennifer L. Tanner. Washington: American Psychological Association.

Widmer, Eric D., and Gilbert Ritschard. 2009. The De-Standardization of the Life Course: Are Men and Women Equal? Advances in Life Course Research 14: 28-39. [CrossRef]

Wight, Vanessa R., Michelle Chau, Yumiko Aratani, Susan Wile Schwarz, and Kalyani Thampi. 2010. A Profile of Disconnected Young Adults in 2010. New York: National Center for Children in Poverty.

(C) 2017 by the author. Licensee MDPI, Basel, Switzerland. This article is an open access article distributed under the terms and conditions of the Creative Commons Attribution (CC BY) license (http:/ / creativecommons.org/licenses/by/4.0/). 